DOI: 10.46340/eppd.2020.7.3.7

Andrii Kapustin

ORCID ID: https://orcid.org/0000-0003-1595-1928

National University "Odesa Law Academy", Ukraine

\title{
LEGAL REGULATION OF THE USE AND PROTECTION IN UKRAINE OF THE EMBLEMS OF THE RED CROSS, RED CRESCENT, RED CRYSTAL
}

\author{
Андрій Капустін \\ Національний університет "Одеська юридична академія», Україна
}

\section{ПРАВОВЕ РЕГУЛЮВАННЯ ВИКОРИСТАННЯ ТА ЗАХИСТУ В УКРАЇНІ ЕМБЛЕМ ЧЕРВОНОГО ХРЕСТА, ЧЕРВОНОГО ПІВМІСЯЦЯ, ЧЕРВОНОГО КРИСТАЛА}

\begin{abstract}
The article considers the implementation of international legal norms and international standards on distinctive emblems in Ukraine and the creation of appropriate mechanisms for the protection of distinctive emblems during the armed conflict in Ukraine. The national features of the organizational and legal mechanism for the implementation of international legal norms and international standards in relation to distinctive emblems have been analyzed. It has been established that the system of the organizational and legal mechanism for the implementation of international legal norms on the use of Emblems is not effective enough, and basically does not have a system of regulations for the implementation of these powers.
\end{abstract}

Keywords: Emblems of the Red Cross, Red Crescent, Red Crystal in Ukraine, international humanitarian law, Geneva Conventions of August 12, 1949, Additional Protocols of June 8, 1977 and December 8, 2005.

Постановка проблеми. 3 початком збройного конфлікту міжнародне гуманітарне право починає виконувати ту саму роль, яка була закладена засновником Міжнародного Комітету Червоного Христа Анрі Дюнаном. Найбільш явно це проявляється у використанні відмітних Емблем із захисною метою, з метою, для якої вони були створені, з метою, яка зробила ці Емблеми пізнавальними у всьому світі як символи гуманісті та захисту.

Незважаючи на те, що держава несе відповідні зобов'язання щодо забезпечення правового регулювання використання та захисту Емблем Червоного Хреста, Червоного Півмісяця, Червоного Кристала у мирний час, ці зобов'язання істотно змінюються у період збройного конфлікту. Для України, на території якої відбувається збройний конфлікт, має вкрай важливе значення неухильне виконання зобов'язань за Женевськими конвенціями від 12 серпня 1949 р. та Додатковими протоколами до них від 8 червня 1977 р. та 8 грудня 2005 р. Це стосується як імплементації відповідних норм у законодавство України, так і створення інституційних засад для забезпечення виконання цих норм.

Аналіз останніх досліджень і публікацій. Слід відмітити, що проблематика щодо відмітних Емблем достатньо добре відображена у спеціальній літературі ${ }^{1}$, включаючи значну кількість практичних видань Міжнародного Комітету Червоного Хреста. Серед вітчизняних авторів це питання також було розглянуто у підручниках, посібниках, монографіях, статтях з міжнародного гуманітарного права. Але що стосується аналізу вітчизняного законодавства у чотирьох площинах: 1) наявність підзаконних актів або процедур, які вимагають норми міжнародного гуманітарного права, міжнародні стандарти Міжнародного Руху Червоного та Червоного Півмісяцю щодо захисту відмітних Емблем або внутрішньодержавне законодавство; 2) безпосередня реалізація в Україні

\footnotetext{
${ }^{1}$ Мельцер Н. (2017). Международное гуманитарное право. Общий курс. Москва: МККК, 184-189.
} 
законодавства щодо відмітних Емблем та захист відмітних Емблем, наявність відповідних механізмів поза збройного конфлікту; 3) безпосередня реалізація в Україні законодавства щодо відмітних Емблем та захист відмітних Емблем, наявність відповідних механізмів захисту у зв'язку зі збройним конфліктом; 4) відповідальність за порушення законодавства щодо відмітних Емблем в Україні, то відповідний спеціальний аналіз у відкритих джерелах майже не проводився. Виключення складають звіти правозахисних організацій щодо порушень міжнародного гуманітарного права у період збройного конфлікту на території України ${ }^{1}$ та публікації Т. Р. Короткого 2 , Є. В. Лук'янченко ${ }^{3}$, О. Прокопишина ${ }^{4}$, Н. В. Хендель ${ }^{5}$, та наші публікації 6 . Але вони більш інформаційний, адже аналітичний формат.

Тому саме аналіз питання імплементації в Україні міжнародно-правових норм та міжнародних стандартів щодо відмітних Емблем та створення відповідних механізмів захисту відмітних Емблем у період збройного конфлікту на території України є основною метою статті.

Виклад основного матеріалу. Відмітні Емблеми Червоного Хреста, Червоного Півмісяця, Червоного Кристала (далі- Емблеми) використовуються із захисною та розпізнавальною метою. Це різне за способом, завданнями та наслідками використання Емблем. Захист і повага до Емблемважливі складові міжнародного гуманітарного права ${ }^{7}$. Будь-яке зловживання Емблемами послаблює їхній захисний ефект і підриває ефективність допомоги, що надається жертвам конфлікту. Як знак приналежності до компонентів Міжнародного Руху Червоного Хреста та Червоного Півмісяця, Емблеми використовуються з розпізнавальною метою, яка має важливе значення для забезпечення гуманітарної діяльності вказаних організацій. Також Емблеми мають на наш погляд символічне значення - рівень поваги до Емблем пропорційний стану дотримання міжнародного гуманітарного права.

Перш за все, Емблема призначена для використання як захисний засіб, зі захисною метою. Використання Емблем у цілях захисту обмежена медичними формуваннями $\mathrm{i}$ санітарнотранспортними засобами, а також медичним i духовним персоналом, обладнанням i запасами за змістом міжнародного гуманітарного права. Таке використання з метою захисту повинно завжди отримати дозвіл зацікавленої воюючої сторони і контролюватися нею ${ }^{8}$. Правове регулювання такого використання основана перш за все на положеннях Женевських конвенцій від 12 серпня 1949 р. та Додаткових протоколах до них від 8 червня 1977 р. та 8 грудня 2005 р.

МКЧХ і Міжнародна Федерація Товариств Червоного Хреста та Червоного Півмісяця можуть використовувати емблему Червоного Хреста повсякчас і для позначення усіх видів діяльності без будь-яких обмежень, як частину логотипу, тобто з розпізнавальною метою, та як з захисною метою.

\footnotetext{
1 Денисенко, Д., Новиков, В., Кориневич, А. (2017). Заборонена мімень: медичні заклади під обстрілами. Звіт за результатами моніторингу фактів застосування заборонених міжнародним правом методів та засобів ведення війни щодо иивільних закладів охорони здоров'я під час збройного конфлікту на Сході України. Київ: Альтернатива.

${ }^{2}$ Короткий, Т., Хендель, Н. (2020). Символ гуманності. Інформаиійне агентство «Украйнське право» $<$ https://ukrainepravo.com/international_law/public_international_law/symvol-gumannosti/> (2020, травень, 07). 3 Лук'янченко, Є. В. (2017). Роль та функції Емблеми Червоного Хреста Через призму порівняльного аналізу законодавства України та Норвегії. Інформаџійне агентство «Украӥнське право»

$<$ https://ukrainepravo.com/international_law/public_international_law/usoe-kha-chtsrnshchkl-yepboyepy-yeuvsrsgsshuyefkha-yeuyei-tuyipts-tsukvryaoersgs-araokits-iansrseav/> (2020, травень, 07).

${ }^{4}$ Прокопишина, О. (2018). Захист гуманності в сучасному світі. Інформаційне агентство «Украйнське право» $<$ https://ukrainepravo.com/international_law/public_international_law/iashyfkh-gtsparrsfkhk-v-ftsafrspts-fvkkhk/> (2020, травень, 07).

${ }^{5}$ Хендель, Н. В. (2016). Міжнародно-правовий захист медичного персоналу під час збройного конфлікту. Інформаційне агентство «Українське право»

$<\mathrm{http}$ ://ukrainepravo.com/international_law/public_international_law/mizhnarodno-pravovyy-zakhyst-medychnogopersonalu-pid-chas-zbroynogo-konfliktu/> (2020, травень, 07).

${ }^{6}$ Капустін, А. В. (2020). Український досвід правового регулювання використання та захисту Емблем

Червоного Хреста, Червоного Півмісяця, Червоного Кристала. Інформаиійне агентство «Украӥнське право» $<\mathrm{https}$ :/ukrainepravo.com/international_law/public_international_law/ukrayinskyy-dosvid-pravovogo-regulyuvannyavykorystannya-ta-zakhystu-emblem-chervonogo-khresta-cherv/> (2020, травень, 07).

${ }^{7}$ Міжнародний комітет Червоного Хреста (2017). Зміцнення поваги до міжнародного гуманітарного права.

Посібник для народних депутатів Украӥни. Київ: МКЧХ, 53-54.

${ }^{8}$ Мельцер Н. (2017). Международное гуманитарное право. Общий курс. Москва: МККК, 184-185.
} 
Емблеми можуть також використовуватися виключно для позначення приналежності, т. б. для того щоб вказати, що особи, обладнання належать до Національних товариств і діяльність здійснюється відповідно до Основоположних принципів Міжнародного Руху Червоного Хреста та Червоного Півмісяця, у порядку, передбаченому внутрішньодержавним законодавством.

У деяких випадках, у мирний час, допускається використання Емблеми іншими організаціями, згідно внутрішньодержавного законодавства, та при наявності відповідного дозволу.

Таким чином, регулювання використання Емблем включає міжнародний рівень (Женевські конвенції від 12 серпня 1949 р. та Додаткові протоколи до них від 8 червня 1977 р. та 8 грудня 2005 р., звичаєве міжнародне гуманітарне право; стандарти МКЧХ; Міжнародної Федерації товариств Червоного Хреста та Червоного Півмісяця) та внутрішньодержавний рівень (законодавство держави, стандарти Національного товариства). Важливим умовно проміжним рівнем є модельні закони, які поєднують в собі міжнародні стандарти та правозастосовну практику 3 найбільш прийнятною для внутрішньодержавного рівня формою.

Таким прикладом $\epsilon$ Model Law concerning the use and protection of the Emblem of the Red Cross, Red Crescent and the Red Crystal. Модельний закон включає положення, що відображають всезагальний правовий режим, який регулює використання та захист Емблем відповідно до вимог Женевських конвенцій від 12 серпня 1949 р. та Додаткових протоколах до них від 8 червня 1977 р. та 8 грудня 2005 р. Ці положення бути імплементовані у національне законодавство шляхом прийняття окремого закону, зразком якого може слугувати Модельний закон ${ }^{1}$. Модельний закон складається із наступних розділів: Загальні положення (2 статті), Правила щодо використання Емблеми (5 статей), Контроль та санкції (7 статей), Заключні положення (2 статі). На сайті МКЧХ окрім тексту Модельного закону розміщено коментар щодо тлумачення та застосування Модельного закону.

Цікавим прикладом імплементації міжнародних норм з використання Емблеми на регіональному рівні $\epsilon$ Модельний закон СНД «Про використання і захист емблем Червоного Хреста або Червоного Півмісяця, найменувань «Червоний Хрест» та «Червоний Півмісяць», розпізнавальних сигналів, що служать для розпізнавання медичних формувань i санітарнотранспортних засобів», який був прийнятий на чотирнадцятому пленарному засіданні Міжпарламентської Асамблеї держав-учасниць СНД (постанова № 14-12 від 16 жовтня 1999 року), та в новій редакції - на тридцять третьому пленарному засіданні Міжпарламентської Асамблеї держав-учасниць СНД (постанова № 33-12 від 3 грудня 2009 року).

Цей Модельний закон фактично є адаптованим перекладом Model Law concerning the use and protection of the Emblem of the Red Cross, Red Crescent and the Red Crystal, 3 тією же структурою та 3 різницею у дві статті. Посилання на Модельний закон СНГ $є$ на сайті МКЧХ ${ }^{2}$ та сайті Верховної ради України ${ }^{3}$. Таким чином, Модельний закон СНГ 1) відповідає міжнародно-правовим нормам, міжнародним стандартам та практиці МКЧХ, у тому числі Модельному закону МЧХУ; 2) регіональним стандартам та особливостям нормотворення на постродянському просторі.

Серед відмінностей Model Law та Модельного закону СНГ - відсутність у Модельного закону СНГ вказівки на національний орган, який загалом відповідає за застосування Закону. Приклади таких органів вказані y Model Law: це Міністерство охорони здоров'я або Міністерство оборони. У коментарі до Model Law вказано, що вкрай важливо визначити, який національний орган несе остаточну відповідальність за застосування цього закону. Тісна співпраця між міністерствами, яких безпосередньо стосуються Закон, загалом міністерствами оборони та охорони здоров'я, була б

\footnotetext{
${ }^{1}$ ICRC (1993). Model Law concerning the use and protection of the Emblem of the Red Cross, Red Crescent and the Red Crystal <https://casebook.icrc.org/case-study/icrc-model-law-concerning-emblem> (2020, травень, 07). ${ }^{2}$ МККК (1999). Модельный закон «Об использовании и защите эмблем Красного Креста или Красного Полумесяиа, наименований «Красный Крест» и «Красный Полумесяи», отличительных сигналов, служащих для опознавания медицинских формирований и санитарно-транспортных средств $<$ https://www.icrc.org/ru/doc/resources/documents/misc/ihl-emblem-3.htm> (2020, травень, 07).

${ }^{3}$ Модельний закон про використання $і$ захист емблем Червоного Хреста, Червоного Півмісяия, Червоного Кристала і найменувань "Червоний Хрест», «Червоний Півмісяиьь,, "Червоний Кристал", відмінних сигналів, які слугують для розпізнавання медичних формувань і санітарно-транспортних засобів, 2009 (СНД). Офіиійний сайт Верховної Ради Украӥни <https://zakon.rada.gov.ua/laws/show/997_o66/card2\#Card> (2020, травень, 07).
} 
доцільним. Національний комітет з імплементації міжнародного гуманітарного права також може зіграти корисну роль у цьому питанні.

Повернемся до другого рівня. Згідно з Женевським конвенціям від 12 серпня 1949 р. та Додатковими протоколами до них від 8 червня 1977 р. та 8 грудня 2005 р., держава зобов'язана імплементувати відповідні норми міжнародного гуманітарного права щодо застосування Емблем та забезпечити достатній рівень їх нормативного регулювання, включаючи застосування ефективних механізмів запобігання неправомірному використанню Емблем, та покарання за таке використання. МКЧХ підготовлено модельний закон щодо Емблем, для уніфікації та створення державами ефективного законодавства ${ }^{1}$.

В Україні в 1999 р. прийнято Закон України «Про символіку Червоного Хреста, Червоного Півмісяця, Червоного Кристала в Україні». Нова редакція Закону прийнята 22 жовтня 2009 року $^{2}$. Закон визначає порядок та умови використання і захисту символіки Червоного Хреста, Червоного Півмісяця, Червоного Кристала на території України відповідно до вимог Женевських Конвенцій про захист жертв війни від 12 серпня 1949 року та Додаткових протоколів до них від 8 червня 1977 року та 8 грудня 2005 року, а також Правил по використанню емблем Червоного Хреста або Червоного Півмісяця Національними товариствами, ухвалених ХХ Віденською Міжнародною конференцією Червоного Хреста 1965 року та переглянутих Радою делегатів у Будапешті у 1991 році, і Резолюції 1, прийнятої на XXIX Міжнародній конференції Червоного Хреста і Червоного Півмісяця у 2006 році. Зміни у Закон було внесено у 2009 р. щодо використання Емблеми Червоного Кристала.

Серед інших нормативних документів у сфері використання та захисту Емблем - відповідні статті Кримінального Кодексу України (ст.ст. 435, 438, 445), Інструкції про порядок виконання норм міжнародного гуманітарного права у Збройних Силах України

Закон України «Про символіку Червоного Хреста, Червоного Півмісяця, Червоного Кристала в Україні» в цілому відповідає положенням Женевським конвенціям від 12 серпня 1949 р. та Додатковим протоколам до них від 8 червня 1977 р. та 8 грудня 2005 р., Правилами по використанню Емблем Червоного Хреста або Червоного Півмісяця Національними

товариствами та Модельним законам. Серед національних особливостей - встановлення організаційно-правового механізму імплементації, включаючи 1) Використання емблеми Червоного Хреста Міністерством оборони України, із застосуванням відповідних контрольних функцій (ст. 4); 2) використання емблеми Червоного Хреста цивільними медичними формуваннями та медичним персоналом, за спеціальним дозволом Міністерства охорони здоров'я України та під його контролем (ст. 5); 3) використання емблеми Червоного Хреста Товариством Червоного Хреста України прямо не вимагає наявності спеціальних правил, але передбачає ї встановлення та контроль за використанням Емблеми (ст. 6); 4) Порядок виготовлення та видачі іменних посвідчень, передбачених устаттях 4, 5, 6 Закону, встановлює Кабінет Міністрів України (ст. 6); 5) використання емблем Червоного Хреста, Червоного Півмісяця, Червоного Кристала для позначення іноземних медичних формувань та інших міжнародних організацій з подання допомоги присутніх на території України, за наявності відповідного погодження з Товариством Червоного Хреста України та офіційного дозволу Кабінету Міністрів України щодо такого перебування та діяльності згідно з чинним законодавством України (ст. 10); 6) використання емблем Червоного Хреста, Червоного Півмісяця, Червоного Кристала Товариством Червоного Хреста України та Товариствами інших держав. Товариство має право використовувати емблему Червоного Хреста як розпізнавальний знак для позначення свого зв'язку з Міжнародним рухом Червоного Хреста та Червоного Півмісяця, а також належності тієї чи іншої особи або об'єкта до Товариства шляхом дотримання умов, визначених Правилами (ст. 10); 7) використання емблеми Червоного Хреста в інших випадках. Дозвіл на використання емблеми на території України у випадках, визначених

\footnotetext{
${ }^{1}$ ICRC (1993). Model Law concerning the use and protection of the Emblem of the Red Cross, Red Crescent and the Red Crystal <https://casebook.icrc.org/case-study/icrc-model-law-concerning-emblem> (2020, травень, 07). 2 Закон про символіку Червоного Хреста, Червоного Півмісяия, Червоного Кристала в Украӥні, 1999 (Верховна Рада України). Офіційний сайт Верховної Ради Украӥни $<$ https://zakon.rada.gov.ua/laws/show/862-14> (2020, травень, 07).

${ }^{3}$ Інструкиія про порядок виконання норм міжнародного гуманітарного права у Збройних Силах Украӥни, 2017 (Міністр оборони України). Офіиійний сайт Верховної Ради України <https://zakon.rada.gov.ua/laws/show/z0704-17> (2020, травень, 07)
} 
цією статтею, надається Національним комітетом Товариства Червоного Хреста України за умови безкоштовного надання послуг (ст. 11); 8) Порядок отримання та реєстрації особистих іменних посвідчень. Порядок отримання та реєстрації особистих іменних посвідчень. Видачу та реєстрацію зазначених посвідчень здійснюють Товариство Червоного Хреста України та уповноважені органи виконавчої влади України в порядку, встановленому Кабінетом Міністрів України (ст. 14); 9) порядок використання зображень емблеми Червоного Хреста або слів «Червоний Хрест» як складових частин логотипів або найменувань підприємств, установ та організацій, заснованих Товариством Червоного Хреста України з метою виконання статутних завдань, визначається Правилами. Рішення про порядок використання емблем у випадках, передбачених частиною четвертою цієї статті, приймається з'їздом Товариства Червоного Хреста України, а в період між з'їздами - на засіданні Президії Товариства з наступним затвердженням його на засіданні Правління Товариства (ст. 15); 10) обов'язки Товариства Червоного Хреста України щодо контролю за використанням символіки Червоного Хреста, Червоного Півмісяця, Червоного Кристала. Товариство Червоного Хреста України зобов'язане сприяти органам державної влади в їх зусиллях щодо запобігання будь-яким зловживанням у використанні символіки Червоного Хреста, Червоного Півмісяця, Червоного Кристала та їх припинення. Товариство має також сповіщати правоохоронні органи та суди про будь-які зловживання, пов'язані з порушеннями у використанні символіки (ст. 16); 11) порядок і умови використання символіки Червоного Хреста, Червоного Півмісяця, Червоного Кристала у разі ії зміни. У разі зміни зазначеної символіки під час збройного конфлікту інформація про цю зміну доводиться оперативно до відома усіх заінтересованих осіб конфліктуючих сторін як представниками Товариства Червоного Хреста України, так і відповідними центральними органами виконавчої влади (Міністерством охорони здоров'я України, Міністерством оборони України, Міністерством закордонних справ України) (ст. 18); 12) Контроль за додержанням Закону здійснюють Міністерство оборони України, Міністерство охорони здоров'я України, Товариство Червоного Хреста України в межах їх компетенції, а також інші органи виконавчої влади відповідно до чинного законодавства (ст. 19); 13) органи державної влади та органи місцевого самоврядування повинні вживати необхідних заходів, передбачених законодавством, з метою запобігання зловживання символікою Червоного Хреста, Червоного Півмісяця, Червоного Кристала, зокрема шляхом поширення інформації про символіку Червоного Хреста, Червоного Півмісяця, Червоного Кристала (ст. 19).

Висновки 3 дослідження і перспективи подальших розвідок у цьому напрямі. Таким чином, в Україні створено нормативну основу для функціонування організаційно-правового механізму імплементації міжнародно-правових норм щодо використання Емблем. На жаль, у дійсності ця система недостатньо ефективна, та переважно не має системи підзаконних актів щодо впровадження цих повноважень. Відповідно ст. 5 Закону України «Про символіку Червоного Хреста, Червоного Півмісяця, Червоного Кристала в Україні», під час збройного конфлікту емблемою Червоного Хреста, що використовується із захисною метою за спеціальним дозволом Міністерства охорони здоров'я України та під його контролем, позначаються цивільний медичний персонал, цивільні лікарні та інші цивільні медичні формування, будівлі, обладнання, медичні матеріали, а також цивільні санітарно-транспортні засоби, заклади охорони здоров'я, призначені, зокрема, для перевезення та розміщення поранених, хворих і потерпілих від аварій судна та догляду за ними. Але, на даний час порядок видачи дозволів щодо використання Емблем у період збройного конфлікту в Україні відсутній. Тому нагальною потребою $є$ моніторинг наявності та ефективності підзаконних актів та внутрішніх правил щодо використання Емблем, та розробка відповідної нормативно-правової основи.

\section{References:}

1. Bartsch, R.I.C. (2016). International Aviation Law: A Practical Guide. Routledge. [in English].

2. Meltser N. (2017). Mezhdunarodnoye gumanitarnoye pravo. Obshchiy kurs [International humanitarian law. General course]. Moscow: ICRC. [in Russian].

3. Denysenko, D., Novykov, V., Korynevych, A. (2017). Zaboronena mishen: medychni zaklady pid obstrilamy. Zvit za rezultatamy monitorynhu faktiv zastosuvannya zaboronenykh mizhnarodnym pravom metodiv ta zasobiv vedennya viyny shchodo tsyvilnykh zakladiv okhorony zdorovya pid chas zbroynoho konfliktu na Skhodi Ukrayiny [Prohibited target: medical facilities under fire. Report on the results of monitoring the use of methods and means of warfare prohibited by international law against civilian health care facilities during the armed conflict in eastern Ukraine]. Kyiv: Alternatyva. [in Ukrainian]. 
4. Korotkii, T., Khendel, N. (2020). Symvol humannosti [Symbol of humanity]. Informatsiyne ahentstvo Ukrayinske pravo [Ukrainian Law Information Agency]

$<$ https://ukrainepravo.com/international_law/public_international_law/symvol-gumannosti/> (2020, May, 07). [in Ukrainian].

5. Lukyanchenko, Y. V. (2017). Rol ta funktsiyi Emblemy Chervonoho Khresta Cherez pryzmu porivnyalnoho analizu zakonodavstva Ukrayiny ta Norvehiyi [The role and functions of the Red Cross Emblem Through the prism of comparative analysis of the legislation of Ukraine and Norway]. Informatsiyne ahentstvo Ukrayinske pravo [Ukrainian Law Information Agency]

$<$ https://ukrainepravo.com/international_law/public_international_law/usoe-kha-chtsrnshchkl-yepboyepyyeuvsrsgs-shuyefkha-yeuyei-tuyipts-tsukvvryaoersgs-araokits-iansrseav/> (2020, May, 07). [in Russian].

6. Prokopyshyna, O. (2018). Zakhyst humannosti v suchasnomu sviti [Protecting humanity in the modern world]. Informatsiyne ahentstvo Ukrayinske pravo [Ukrainian Law Information Agency]

$<$ https://ukrainepravo.com/international_law/public_international_law/iashyfkh-gtsparrsfkhk-v-ftsafrspts-fvkkhk/> (2020, May, 07). [in Ukrainian].

7. Khendel, N. V. (2016). Mizhnarodno-pravovyy zakhyst medychnoho personalu pid chas zbroynoho konfliktu [International legal protection of medical personnel during armed conflict]. Informatsiyne ahentstvo Ukrayinske pravo [Ukrainian Law Information Agency] <http://ukrainepravo.com/international_law/public_international_law/ mizhnarodno-pravovyy-zakhyst-medychnogo-personalu-pid-chas-zbroynogo-konfliktu/> $(2020$, May, $\overline{07})$. [in Ukrainian].

8. Kapustin, A. V. (2020). Ukrayinskyy dosvid pravovoho rehulyuvannya vykorystannya ta zakhystu Emblem Chervonoho Khresta, Chervonoho Pivmisyatsya, Chervonoho Krystala [Ukrainian experience of legal regulation of use and protection of Red Cross, Red Crescent and Red Crystal Emblems]. Informatsiyne ahentstvo Ukrayinske pravo [Ukrainian Law Information Agency]

$<$ https://ukrainepravo.com/international_law/public_international_law/ukrayinskyy-dosvid-pravovogoregulyuvannya-vykorystannya-ta-zakhystu-emblem-chervonogo-khresta-cherv/> (2020, May, 07). [in Ukrainian].

9. International Committee of the Red Cross (2017). Zmitsnennya povahy do mizhnarodnoho humanitarnoho prava. Posibnyk dlya narodnykh deputativ Ukrayiny [Strengthening respect for international humanitarian law. Handbook for People's Deputies of Ukraine]. Kyiv: ICRC. [in Ukrainian].

10. ICRC (1993). Model Law concerning the use and protection of the Emblem of the Red Cross, Red Crescent and the Red Crystal <https://casebook.icrc.org/case-study/icrc-model-law-concerning-emblem> (2020, May, 07). [in English].

11. ICRC (1999). Modelnii zakon ob ispolzovanii i zashchite emblem Krasnogo Kresta ili Krasnogo Polumesyatsa, naimenovaniy Krasnyy Krest i Krasnyy Polumesyats, otlichitelnykh signalov, sluzhashchikh dlya opoznavaniya meditsinskikh formirovaniy i sanitarno-transportnykh sredstv [Model law on the use and protection of the Red Cross or Red Crescent emblems, the names Red Cross and Red Crescent, distinctive signals used to identify medical units and sanitary vehicles] <https:/www.icrc.org/ru/doc/resources/documents/misc/ihl-emblem-3.htm> (2020, May, 07). [in Russian].

12. Modelnyy zakon pro vykorystannya i zakhyst emblem Chervonoho Khresta, Chervonoho Pivmisyatsya, Chervonoho Krystala i naymenuvan Chervonyy Khrest, Chervonyy Pivmisyats, Chervonyy Krystal, vidminnykh syhnaliv, yaki sluhuyut dlya rozpiznavannya medychnykh formuvan i sanitarno-transportnykh zasobiv, 2009 (SND) [Model law on the use and protection of emblems of the Red Cross, Red Crescent, Red Crystal and the names Red Cross, Red Crescent, Red Crystal, distinctive signals used to recognize medical formations and ambulances, 2009 (CIS )]. Ofitsiynyy sayt Verkhovnoyi Rady Ukrayiny [Official site of the Verkhovna Rada of Ukraine] <https://zakon.rada.gov.ua/laws/show/997_o66/card2\#Card> (2020, May, 07). [in Ukrainian].

13. Zakon pro symvoliku Chervonoho Khresta, Chervonoho Pivmisyatsya, Chervonoho Krystala v Ukrayini, 1999 (Verkhovna Rada Ukrayiny). [Law on Symbols of the Red Cross, Red Crescent, Red Crystal in Ukraine, 1999 (Verkhovna Rada of Ukraine)] Ofitsiynyy sayt Verkhovnoyi Rady Ukrayiny [Official site of the Verkhovna Rada of Ukraine] < https://zakon.rada.gov.ua/laws/show/862-14> (2020, May, 07). [in Ukrainian].

14. Instruktsiya pro poryadok vykonannya norm mizhnarodnoho humanitarnoho prava u Zbroynykh Sylakh Ukrayiny, 2017 (Ministr oborony Ukrayiny). [Instruction on the procedure for implementing the norms of international humanitarian law in the Armed Forces of Ukraine, 2017 (Minister of Defense of Ukraine).] Ofitsiynyy sayt Verkhovnoyi Rady Ukrayiny [Official site of the Verkhovna Rada of Ukraine] $<$ https://zakon.rada.gov.ua/laws/show/z0704-17> (2020, May, 07). [in Ukrainian]. 